\section{Harvest Date and Crop Load Effects on a Carbon Dioxide-related Storage Injury of 'Braeburn' Apple}

\author{
H. John Elgar, Christopher B. Watkins ${ }^{1}$, and Nagin Lallu \\ Mt. Albert Research Centre, Postharvest Science Group, The Horticulture \\ and Food Research Institute of New Zealand Ltd., P.O. Box 92169, Auckland, \\ New Zealand
}

Additional index words. Malus $\times$ domestica, “'Braeburn' browning disorder”, physiological disorder, skin permeance, calcium, magnesium, potassium, maturity, ethylene

\begin{abstract}
The incidence and severity of "Braeburn' browning disorder" (BBD), a $\mathrm{CO}_{2}$ induced disorder of 'Braeburn' apple (Malus $\times$ domestica Borkh.), vary markedly with production district and orchard block. We investigated the effects of harvest date, blush, and crop load on fruit maturity, minerals, skin permeance, and BBD incidence. Incidence of BBD was higher in late- than in early-harvested fruit and in fruit on light than on heavily cropping trees, but blush intensity did not influence susceptibility to the disorder. Fruit maturity factors were affected by region, harvest date, blush type, and crop load, but no consistent relationships between these factors and BBD occurrence were found. Concentrations of $\mathrm{Ca}, \mathrm{Mg}$, and/or $\mathrm{K}$ were influenced by harvest date, blush type, and crop load, and skin permeance to gas exchange was affected by growing region and blush type, but not by harvest date or crop load. However, no physiological or mineral factor measured in this study was strongly correlated with susceptibility of fruit to BBD. Fruit from orchards that have a history of susceptibility to BBD, or subjected to adverse harvest date, regional, crop load, microclimate, and seasonal influences, should be segregated at harvest, and should not be held in controlled-atmosphere (CA) storage. Crop load should be managed to reduce the occurrence of biennial bearing.
\end{abstract}

A disorder known as “"Braeburn' browning disorder" (BBD), a $\mathrm{CO}_{2}$-related disorder, can develop in the flesh of 'Braeburn' apples during storage (Elgar et al., 1998; Lau, 1998). The disorder has characteristics typical of other $\mathrm{CO}_{2}$ injuries, such as brownheart and cavity formation in the flesh (Lidster et al., 1990). Symptoms can be induced by elevated $\mathrm{CO}_{2}$, and can be aggravated by depressed $\mathrm{O}_{2}$ partial pressures in storage (Elgar et al., 1998; Lau, 1998), and by methyl bromide fumigation (Lay-Yee, 1993). However, BBD can develop in fruit either prior to harvest or during air storage (personal observations).

Susceptibility of 'Braeburn' apples to BBD has damaged commercial confidence in the cultivar. Occurrence can be erratic as a result of unknown preharvest factors that influence

\footnotetext{
Received for publication 20 May 1998. Accepted for publication 21 Sept. 1998. This research was supported by the New Zealand Apple and Pear Marketing Board [ENZA New Zealand (International)] and the Foundation for Research Science and Technology (Contract number CO6627). We thank Paul Brookfield for assistance with fruit harvesting and determining crop load factors, Sally Roughan for mineral analyses, and Melissa Miller and Marcus Davy for statistical analyses. The cost of publishing this paper was defrayed in part by the payment of page charges. Under postal regulations, this paper therefore must be hereby marked advertisement solely to indicate this fact.

${ }^{1}$ Associate Professor. Current address: Dept. of Fruit and Vegetable Science, Cornell Univ., Ithaca, NY 14853-5908. E-mail: cbw3@cornell.edu.
}

susceptibility; identification of these factors would increase confidence among marketers. Little information is available in the literature about preharvest effects on either external or internal $\mathrm{CO}_{2}$ injuries in apple fruit. Most of these injuries are associated with incorrect storage conditions, such as poor ventilation during air storage (Carne, 1950), but the disorder is often associated with controlledatmosphere (CA) storage (Blanpied and Smock, 1961; Bramlage et al., 1977; Wilkinson and Fidler, 1973). Research therefore has focused on identification of safe atmospheres and defining postharvest strategies, such as keeping $\mathrm{CO}_{2}$ concentrations low during the early stages of storage when the risk of injury is highest, treatment with diphenylamine, or delaying the period between harvest and transfer to CA storage (Elgar et al., 1998; Johnson et al., 1998; Smock and Blanpied, 1972; Watkins et al., 1997).

Preliminary studies indicate that the incidence and severity of the disorder are higher in fruit grown in colder or more southern regions, or in colder or higher altitude districts within a region in New Zealand, and that large variations in incidence can occur among both orchards within regions, and trees within orchards (unpublished observations). Several possible factors contributing to greater fruit susceptibility to the disorder were identified, including late harvest, light crop load, and low blush. The objective of this study was to assess the importance of these factors on BBD incidence, using fruit from four orchards in each of two districts.
Plant material. 'Braeburn' apples from each of four orchards in each of the Central Hawke's Bay and Central Otago regions of New Zealand were harvested during the first, middle, and final week of the commercial season (4 weeks) of 1994 for each district (29 Mar., 12 Apr., and 26 Apr. for Central Hawke's Bay, and 5 Apr., 19 Apr., and 3 May for Central Otago harvests, respectively). Within each orchard, five trees with either high or low crop load were identified by visual assessment prior to harvest, and trunk girth and number of fruit on each tree were recorded. At each harvest, 64 fruit (average fruit weight $180 \mathrm{~g}$; range 160-200 g) were graded into two blush categories (intense blush on $>50 \%$ of the surface vs. no blush or weak blush on $<50 \%$ of the surface), packed into standard (18.5 kg) export apple cartons, and transported to the Mt. Albert Research Centre in Auckland that same day.

Harvest quality. Internal ethylene concentration (IEC), background skin color, flesh firmness, soluble solids concentration, and starch pattern indices were determined for 10 fruit from each orchard, crop load, and blush category. Opposite segments from each of five apples were combined to provide two samples for each replicate, and frozen for later determination of titratable acidity. For ethylene determinations, 1-mL samples of internal gas were drawn into a syringe through a hypodermic needle inserted into the core cavity of each fruit, and ethylene content was measured using gas chromatography (Philips PU4500 gas chromatograph, Pye Unicam Ltd., Cambridge, England; $1.5 \mathrm{~m} \times 6 \mathrm{~mm}$ alumina F1 80/100 mesh column; injection, detector, and column temperatures 160,200 , and $130{ }^{\circ} \mathrm{C}$, respectively). Background color was assessed visually on industry color cards ranging from 1 (green) to 7 (yellow). Flesh firmness was determined with a semi-automated firmness tester (EPT-1; Lake City Technical Products Inc., Canada) on pared surfaces on two opposite sides of each fruit. Soluble solids concentration of each fruit was determined with a refractometer (Atago model PR-1; Atago Co. Ltd., Tokyo) using the juice expressed during firmness determination. Titratable acidity was determined on a composite sample of each replicate with an auto-titrator (Mettler DL40 RC; Mettler Instruments AG, Zurich, Switzerland). Acids were measured by titrating $20 \mathrm{~g}$ of diluted, blended apple tissue against $0.1 \mathrm{~N}$ $\mathrm{NaOH}$ to a $\mathrm{pH} 8.1$ endpoint, in triplicate, and results are expressed as meq/g fresh weight. Starch content was determined by dipping the cut half of each fruit into an $\mathrm{I}_{2} / \mathrm{KI}$ solution for $30 \mathrm{~s}$, allowing the fruit surface to develop color over several min. The resulting patterns were compared with the ENZA 'Braeburn' starch pattern chart (New Zealand Apple and Pear Marketing Board, Hastings, 1992).

Skin permeance of four fruit from each orchard, harvest, crop load, and blush category was measured using a slightly modified version of the nonsteady state ethane efflux method (Banks, 1985) as described by Yearsley (1996). Briefly, $1 \mathrm{~mL}$ of compressed pure 
ethane was injected into 1.16-L jars containing individual fruit of known weight and left overnight to equilibrate at $20{ }^{\circ} \mathrm{C}$. Fruit were removed from the jars in a fume hood, exposed briefly to a fan to disturb the boundary layer of the fruit, and sealed in a jar of the same volume with a magnetic stirrer operating. One-milliliter gas samples were withdrawn from the jars every $15 \mathrm{~s}$ for $2 \mathrm{~min}$ to determine the time course of ethane efflux from the fruit. Permeance was calculated from Fick's First Law of Diffusion (Banks, 1985).

Concentrations of $\mathrm{Ca}, \mathrm{Mg}$, and $\mathrm{K}$ in six pooled samples of five fruit from each orchard, crop load, and blush type at early and late harvests were determined by atomic absorption. Fruit samples were dried at $70{ }^{\circ} \mathrm{C}$, ground in a laboratory mill (Cyclotec, Tecator $\mathrm{AB}$, Hoganas, Sweden), and digested in $\mathrm{HNO}_{3}$ $: \mathrm{HClO}_{4}$ prior to analysis by atomic absorption (GBC AA spectrophotometer; GBC Scientific Equipment Pty. Ltd., Dandenong, Victoria, Australia).

Storage procedures. Fifty fruit from each orchard, crop load, and blush category were packed into cartons, placed into 330-L plastic chambers, and cooled overnight. On the day after harvest, the chambers were sealed with stainless steel lids and a controlled atmosphere of $2 \mathrm{kPa} \mathrm{O}_{2}: 2 \mathrm{kPaCO}_{2}$ was flushed through each chamber at a flow rate of $18 \mathrm{~L} \cdot \mathrm{h}^{-1}$ (greater than two air changes per day) and mixed continuously with a fan. Equilibrated atmospheres were obtained within $3 \mathrm{~d}$ of harvest. Chambers were monitored twice weekly by analyzing 1-mL gas samples for oxygen and carbon dioxide using an oxygen sensor (Citicel C/S; City Technology Ltd., London, U.K.) and an infrared detection cell (Servomex 01514/701 infrared transducer; Servomex PLC Crowborough, East Sussex, U.K.), respectively.

The fruit were held under CA storage for 12 weeks at $0 \pm 0.5^{\circ} \mathrm{C}$. Flesh firmness and soluble solids content of 10 fruit per category were subsequently measured after $1 \mathrm{~d}$ at $20^{\circ} \mathrm{C}$. After a further $6 \mathrm{~d}$ at $20^{\circ} \mathrm{C}$, the remaining 40 fruit from each category were sliced several times to evaluate the presence and severity of internal and external disorders. Flesh browning and cavities were assessed separately. Flesh browning was described as slight, moderate, or severe, depending on the degree of browning in the flesh of the fruit and whether the disorder was visible through the skin. Cavities appeared either in the core or flesh of the fruit. Symptoms were described as "slight" if the cavities were confined to the core of the fruit and did not affect its edibility; "moderate" if the cavities were more extensive, but still largely confined to the core; and "severe" if the cavities had progressed to the cortical flesh. Overall disorder severity was rated as a combination of incidence of flesh browning and cavities, taking into account those instances where individual fruit had symptoms of both disorders. Flesh browning, cavity, and overall disorder scores were determined by multiplying the incidence at each severity by a weighted score $(1=$ slight, 2 = medium, $3=$ severe) and dividing by the total number of fruit, to give an average value for each treatment.

Statistical analyses. Analysis of variance was used to make inferences from the randomized complete-block designs. Percentage data were arcsine transformed to obtain homogeneity of variance. Relationships between measured variables were examined using pairwise scatter plots. No significant relationships were found that justified further regression analysis.

\section{Results}

Crop load estimations. High crop load trees had an average of 7.2 fruit $/ \mathrm{cm}^{2}$ trunk cross-sectional area (TCA), almost double the load factor of low crop load trees at 3.4 fruit/ $\mathrm{cm}^{2}$ TCA (Table 1). Trees from Central Hawke's Bay had higher crop loads than did those from Central Otago, although average crop loads varied considerably among orchards.

Maturity at harvest. Only starch pattern indices and titratable acidity concentrations were affected by region, with fruit from Central Otago having higher starch pattern indices (less starch) and lower titratable acidity than those from Central Hawke's Bay (Table 2). All factors assessed indicated that fruit were more mature at later than at early harvest, but effects of blush and crop load on maturity were not always consistent. High blush fruit were more mature, on the basis of IEC, background color, soluble solids, and titratable acidity, but also had a slightly lower starch pattern index (more starch) and were firmer than low blush fruit. Crop load did not affect starch pattern index or soluble solids. Although fruit from low crop load trees were more mature on the basis of IEC and background color than those from high crop load trees, they were firmer and had higher titratable acidity.

Interactions between region, harvest date, background color, soluble solids, starch pattern index, and flesh firmness, but these interactions were not consistent across the various physiological factors (data not shown).

Mineral analyses. Calcium, $\mathrm{Mg}$, and $\mathrm{K}$ concentrations in the fruit did not differ between regions (Table 2). Fruit from the last harvest had higher $\mathrm{Mg}$ and $\mathrm{K}$ concentrations crop load, and blush were detected for IEC,

than fruit from the first harvest, but Ca was not affected by harvest date. High blush fruit had lower $\mathrm{Ca}$ and $\mathrm{K}$ concentrations than did low blush fruit, but $\mathrm{Mg}$ concentrations were unaffected. Calcium concentrations were higher, and $\mathrm{Mg}$ and $\mathrm{K}$ concentrations lower, in fruit from high crop load trees than in those from low crop load trees.

Skin permeance. Skin permeance was lower in fruit from Central Otago than in those from Central Hawke's Bay, and in high blush than in low blush fruit, but was not affected by harvest date or crop load (Table 2). Because BBD is a population-based phenomenon, outliers within the population may be more useful in explaining treatment effects; while treatment means may be similar, the susceptible fruit might be associated with lower permeance, and, consequently, a higher internal $\mathrm{CO}_{2}$ concentration. Box plot analyses showed a slightly greater number of outliers in the fruit population from late-harvested trees (Fig. 1), which would support the possibility that skin permeance is involved in fruit susceptibility to BBD. However, the greater range in permeance in low blush fruit than in high blush fruit was not supported by differences in BBD incidence.

Flesh browning and cavity incidence. Because BBD appears in two forms, as flesh browning and as cavities (Elgar et al., 1998), we assessed each disorder individually. No difference in flesh browning incidence or severity was detected between fruit from Central Hawke's Bay and Central Otago (Table 3), perhaps because the variation between orchards within a district was high. Incidence of cavities was greater in Central Otago fruit (Table 3). Incidence and severity of flesh browning increased as harvest was delayed, and were higher with low crop loads (Table 3 ). The incidence, but not severity, of cavities declined as harvest was delayed, and both were higher in fruit from low crop load trees. There was no effect of blush intensity, although the disorder generally was found on the shaded side of blushed fruit (data not shown).

Firmness and soluble solids concentration were not affected by region (Table 3). Late harvested fruit were softer and had greater soluble solids. Low blush fruit and fruit from high crop load trees were also softer, but had lower soluble solids concentrations.

Table 1. Crop load of 'Braeburn' trees in orchards in Central Hawke's Bay and Central Otago, New Zealand.

\begin{tabular}{|c|c|c|c|}
\hline \multirow[b]{2}{*}{ Orchard } & \multirow[b]{2}{*}{ Nominal crop load } & \multicolumn{2}{|c|}{ Crop load (fruit/cm ${ }^{2} \mathrm{TCA}^{z}$ ) } \\
\hline & & Central Hawke's Bay & Central Otago \\
\hline \multirow[t]{2}{*}{1} & High & 9.8 & 4.0 \\
\hline & Low & 4.2 & 2.5 \\
\hline \multirow[t]{2}{*}{2} & High & 8.2 & 6.6 \\
\hline & Low & 2.7 & 3.3 \\
\hline \multirow[t]{2}{*}{3} & High & 9.9 & 5.3 \\
\hline & Low & 5.4 & 2.4 \\
\hline \multirow[t]{2}{*}{4} & High & 7.8 & 6.2 \\
\hline & Low & 2.9 & 4.2 \\
\hline \multirow[t]{2}{*}{ Average } & High & 8.9 & 5.5 \\
\hline & Low & 3.8 & 3.1 \\
\hline \multirow[t]{3}{*}{ SE } & Region (R) & \multirow{3}{*}{\multicolumn{2}{|c|}{$\begin{array}{l}0.75^{\text {*** }} \\
0.32^{\text {*** }} \\
0.69^{\text {*** }}\end{array}$}} \\
\hline & Crop load (C) & & \\
\hline & $\mathrm{R} \times \mathrm{C}$ & & \\
\hline
\end{tabular}

${ }^{\mathrm{z} T C A}=$ trunk cross-sectional area.

${ }^{* * *}$ Significant at $P \leq 0.001$ 
Table 2. Main effects of growing region, harvest time, crop load, and blush type on physiological factors of 'Braeburn' apples measured at harvest.

\begin{tabular}{|c|c|c|c|c|c|c|c|c|c|c|}
\hline \multirow[b]{2}{*}{ Factor } & \multirow{2}{*}{$\begin{array}{c}\text { Internal } \\
\text { ethylene } \\
\text { concentration } \\
\left(\mu \mathrm{L} \cdot \mathrm{L}^{-1}\right)\end{array}$} & \multirow{2}{*}{$\begin{array}{c}\text { Starch } \\
\text { pattern } \\
\text { index } \\
(0-8)\end{array}$} & \multirow{2}{*}{$\begin{array}{l}\text { Background } \\
\text { color } \\
(1-7)\end{array}$} & \multirow{2}{*}{$\begin{array}{l}\text { Flesh } \\
\text { firmness } \\
(\mathrm{N})\end{array}$} & \multirow{2}{*}{$\begin{array}{l}\text { Soluble } \\
\text { solids } \\
(\%)\end{array}$} & \multirow{2}{*}{$\begin{array}{c}\text { Titratable } \\
\text { acidity } \\
\left(\mathrm{meq} / \mathrm{g} \mathrm{FW}^{\mathrm{z}}\right)\end{array}$} & \multirow{2}{*}{$\begin{array}{c}\text { Skin } \\
\text { permeance } \\
\left(\mathrm{nmol} \mathrm{m}{ }^{-2} \cdot \mathrm{s}^{-1} \cdot \mathrm{Pa}^{-1}\right)\end{array}$} & \multicolumn{3}{|c|}{$\begin{array}{l}\text { Fruit mineral concn } \\
\quad\left(\mu \mathrm{g} \cdot \mathrm{g}^{-1} \mathrm{FW}^{\mathrm{z}}\right)\end{array}$} \\
\hline & & & & & & & & $\mathrm{Ca}$ & $\mathrm{Mg}$ & $\mathrm{K}$ \\
\hline \multicolumn{11}{|l|}{ Region } \\
\hline Central H.B. ${ }^{\text {y }}$ & 0.33 & 2.3 & 3.1 & 94 & 11.2 & 0.17 & 0.211 & 24 & 32 & 1000 \\
\hline \multirow[t]{2}{*}{ Central Otago $^{x}$} & 0.37 & 3.5 & 3.0 & 93 & 10.8 & 0.16 & 0.186 & 29 & 34 & 1060 \\
\hline & NS & $* * *$ & NS & NS & NS & $*$ & $* * *$ & NS & NS & NS \\
\hline \multicolumn{11}{|l|}{ Harvest } \\
\hline 1 & 0.16 & 2.1 & 2.3 & 98 & 10.4 & 0.18 & 0.206 & 27 & 31 & 990 \\
\hline 2 & 0.46 & 2.8 & 2.8 & 95 & 11.1 & 0.16 & 0.195 & --- & --- & --- \\
\hline \multirow[t]{2}{*}{3} & 0.43 & 3.8 & 4.0 & 88 & 11.6 & 0.15 & 0.194 & 26 & 35 & 1070 \\
\hline & $* * *$ & $* * *$ & $* * *$ & $* * *$ & $* * *$ & $* * *$ & NS & NS & $* * *$ & $* * *$ \\
\hline \multicolumn{11}{|l|}{ Blush type } \\
\hline Low & 0.24 & 3.1 & 2.6 & 93 & 10.6 & 0.17 & 0.206 & 28 & 33 & 1050 \\
\hline \multirow[t]{2}{*}{ High } & 0.45 & 2.7 & 3.5 & 95 & 11.5 & 0.16 & 0.191 & 26 & 33 & 1010 \\
\hline & $* * *$ & $* * *$ & $* * *$ & $* * *$ & $* * *$ & $*$ & $* *$ & $* * *$ & NS & $*$ \\
\hline \multicolumn{11}{|l|}{ Crop load } \\
\hline Low & 0.39 & 2.9 & 3.1 & 95 & 11.0 & 0.17 & 0.198 & 25 & 34 & 1090 \\
\hline \multirow[t]{2}{*}{ High } & 0.30 & 2.9 & 3.0 & 92 & 11.0 & 0.16 & 0.199 & 28 & 32 & 970 \\
\hline & $* * *$ & NS & $*$ & $* * *$ & NS & $* * *$ & NS & $* * *$ & $* * *$ & $* * *$ \\
\hline
\end{tabular}

${ }^{\mathrm{z}} \mathrm{FW}=$ fresh weight.

y Central Hawke's Bay, New Zealand.

${ }^{x}$ Central Otago, New Zealand.

ns, *,**,**Nonsignificant or significant at $P \leq 0.05,0.01$, or 0.001 , respectively, within each factor.
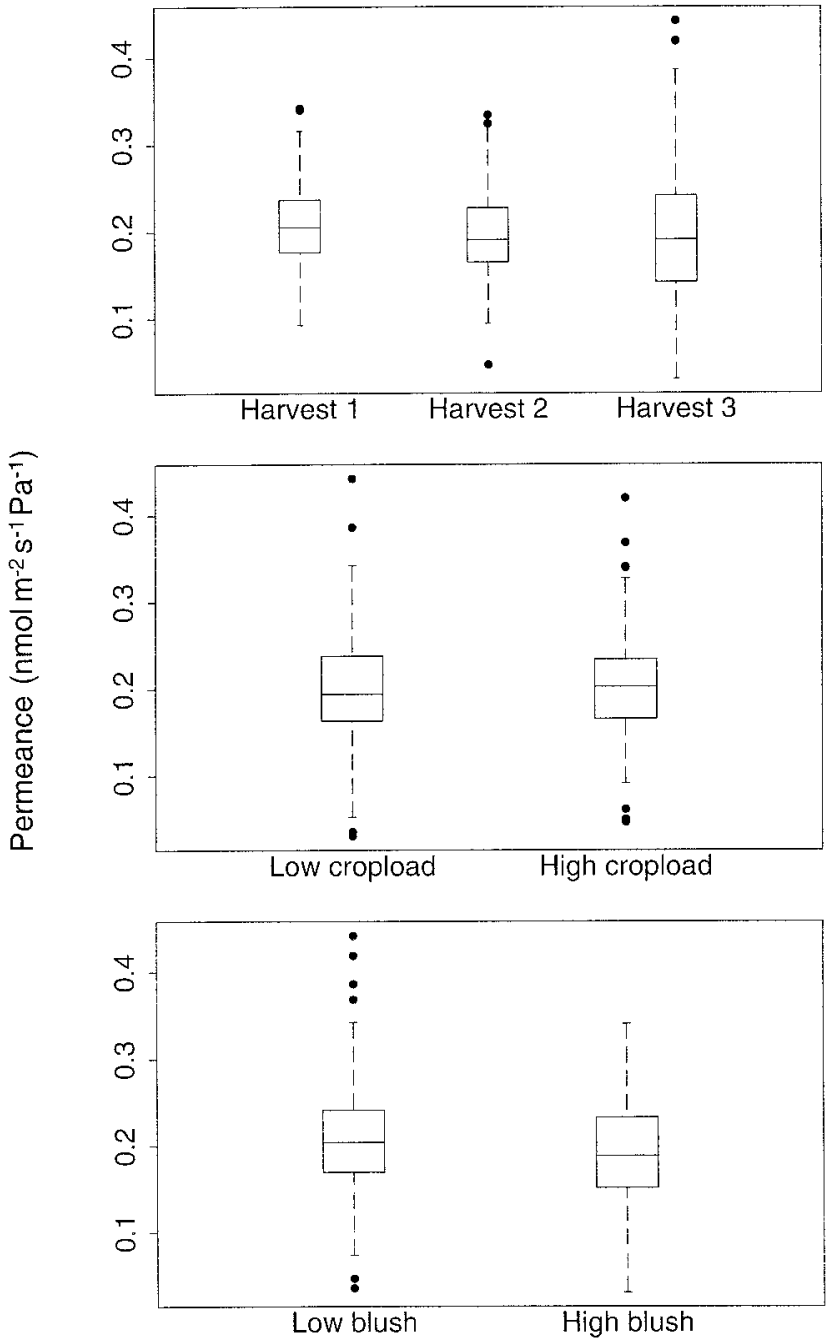

Fig. 1. Box plot analysis of effects of harvest date, crop load, and blush on skin permeance to gas exchange in 'Braeburn' apple fruit. The box represents the 25 th to 75 th percentile around the median line, the vertical lines outside the box represent the $99 \%$ confidence limits, and the points represent data outside these limits.

\section{Discussion}

Fruit from both regions had similar BBD occurrence as expressed as flesh browning, although cavity incidence and severity were highest in fruit from Central Otago. However, variability of disorder incidence was high among orchards. Such variability is a general feature of fruit susceptibility to $\mathrm{CO}_{2}$ injuries (Elgar et al., 1998; Johnson et al., 1998; Lau and Looney, 1978; Volz et al., 1998; Watkins et al., 1997).

Despite variations among orchards, BBD incidence, expressed as flesh browning, was consistently higher in later harvested fruit and in fruit from trees with low crop loads. In contrast, cavity incidence, though not severity, was slightly higher in the early harvested fruit than in fruit from subsequent harvests. Harvest date has been implicated in fruit susceptibility to $\mathrm{CO}_{2}$ injury, higher levels of external and internal injury being associated with early and late harvest, respectively (Meheriuk, 1977; Smock and Blanpied, 1963). Crop load has not previously been shown to influence $\mathrm{CO}_{2}$ injury, but fruit from low crop load trees are generally more susceptible to other storage disorders (Ferguson and Watkins, 1992; Sharples, 1964; Volz et al., 1993).

Maturity, as affected by harvest date and crop load, was not consistently related to BBD occurrence. Measurements of IEC and background color indicated that fruit from late harvest and low crop load trees were the most mature; although late harvested fruit had higher starch indices and soluble solids concentrations, neither factor was affected by crop load. Later harvested fruit were softer than early harvested fruit, and fruit from high crop load trees were slightly softer. In contrast, blush type, which did not affect BBD occurrence, affected all maturity factors. Therefore, even though later harvest of fruit and low crop load appear to be major factors contributing to fruit 
Table 3. Main effects of growing region, harvest time, crop load, and blush type on incidence and severity scores for flesh browning, cavities and total disorders, and flesh firmness and soluble solids, of 'Braeburn' apples. Fruit were stored under controlled-atmosphere $\left(2 \mathrm{kPa} \mathrm{CO}_{2}: 2 \mathrm{kPa} \mathrm{O}_{2}\right)$ conditions at $0{ }^{\circ} \mathrm{C}$ for 12 weeks and assessed after $1 \mathrm{~d}$ (firmness and soluble solids) and $7 \mathrm{~d}$ (disorders) at $20^{\circ} \mathrm{C}$.

\begin{tabular}{|c|c|c|c|c|c|c|c|c|}
\hline \multirow[b]{2}{*}{ Factor } & \multicolumn{2}{|c|}{ Flesh browning } & \multicolumn{2}{|c|}{ Cavities } & \multicolumn{2}{|c|}{ Total disorder } & \multirow{2}{*}{$\begin{array}{l}\text { Firmness } \\
(\mathrm{N})\end{array}$} & \multirow{2}{*}{$\begin{array}{c}\text { Soluble } \\
\text { solids (\%) }\end{array}$} \\
\hline & $\overline{(\%)}$ & $\overline{\text { (score) }}$ & $\overline{(\%)}$ & $\overline{\text { (score) }}$ & $\overline{(\%)}$ & $\overline{\text { (score) }}$ & & \\
\hline \multicolumn{9}{|l|}{ Region } \\
\hline Central H.B. ${ }^{z}$ & 21 & 0.8 & 29 & 0.6 & 45 & 1.4 & 92 & 12.8 \\
\hline \multirow[t]{2}{*}{ Central Otago ${ }^{y}$} & 32 & 1.0 & 45 & 1.0 & 64 & 2.0 & 91 & 11.7 \\
\hline & NS & NS & $* *$ & $*$ & $* * *$ & NS & NS & NS \\
\hline \multicolumn{9}{|l|}{ Harvest } \\
\hline 1 & 13 & 0.4 & 44 & 0.9 & 50 & 1.2 & 94 & 11.9 \\
\hline 2 & 23 & 0.8 & 35 & 0.8 & 49 & 1.5 & 90 & 12.3 \\
\hline \multirow[t]{2}{*}{3} & 44 & 1.6 & 33 & 0.8 & 64 & 2.4 & 90 & 12.5 \\
\hline & $* * *$ & $* * *$ & $* *$ & NS & $* *$ & $* * *$ & $* * *$ & $* * *$ \\
\hline \multicolumn{9}{|l|}{ Blush type } \\
\hline Low & 25 & 0.9 & 37 & 0.8 & 54 & 1.7 & 90 & 11.7 \\
\hline \multirow[t]{2}{*}{ High } & 28 & 0.9 & 37 & 0.8 & 56 & 1.7 & 92 & 12.8 \\
\hline & NS & NS & NS & NS & NS & NS & $* * *$ & $* * *$ \\
\hline \multicolumn{9}{|l|}{ Crop load } \\
\hline Low & 39 & 1.3 & 45 & 1.0 & 72 & 2.4 & 92 & 12.4 \\
\hline \multirow[t]{2}{*}{ High } & 14 & 0.4 & 29 & 0.6 & 37 & 1.2 & 90 & 12.1 \\
\hline & $* * *$ & $* * *$ & $* * *$ & $* * *$ & $* * *$ & $* * *$ & $* * *$ & *** \\
\hline
\end{tabular}

${ }^{2}$ Central Hawke's Bay, New Zealand.

${ }^{\mathrm{y}}$ Central Otago, New Zealand.

ss, $, * * *, * * *$ Nonsignificant or significant at $P \leq 0.05,0.01$, or 0.001 , respectively, within each factor.

susceptibility to BBD, collectively these data do not establish critical maturity factors that might be used to predict susceptibility.

Greater incidence of external and internal $\mathrm{CO}_{2}$ injury in 'Golden Delicious' apples was associated with higher fruit $\mathrm{N}, \mathrm{Mn}$, and $\mathrm{Zn}$, and lower $\mathrm{K}$ and $\mathrm{Mg}$, but not with $\mathrm{Ca}$ (Lau and Looney, 1978). In our study, with more limited mineral analyses, Ca concentrations were not affected by harvest date, but $\mathrm{Mg}$ and $\mathrm{K}$ were higher at the last than at the first harvest. Fruit from trees with low crop loads had lower $\mathrm{Ca}$ and higher $\mathrm{Mg}$ and $\mathrm{K}$ concentrations than those from trees with high crop load. Light cropping can have a profound effect on fruit storage quality and $\mathrm{Ca}$ concentrations are lower in fruit from trees with low crop regardless of fruit size (Ferguson and Watkins, 1992). Although differences in mineral concentrations between treatments were small, more widespread analyses of these minerals may be warranted to further explore possible relationships with BBD incidence. The confounding effect of crop load on relationships between minerals and BBD incidence should be considered.

Low permeance to gas exchange has been implicated in greater susceptibility of fruit to low $\mathrm{O}_{2}$ injury (Park et al., 1993). Less is known about possible relationships between permeance and high $\mathrm{CO}_{2}$ injury. Johnson et al. (1998) detected a close association between low permeance and internal, but not external, $\mathrm{CO}_{2}$ injury in 'Bramley's Seedling' apples, however, no similar relationships were found in 'Fuji' apples (Park and Lee, 1991; Volz et al., 1998). 'Braeburn' has a low, but variable, permeance compared with many other apple cultivars (Rajapakse et al., 1990; Yearsley et al., 1996, 1997), which could contribute to its sensitivity to BBD. We were not able to detect significant treatment differences associated with skin permeance that might be related to BBD incidence, although further study is required to examine if the number of outlying fruit with low permeance might contribute to increased injury in certain fruit within the population. However, other cultivars that are susceptible to internal $\mathrm{CO}_{2}$ injury, such as 'Fuji' (Volz et al., 1998), do not have markedly low skin permeance (Park and Lee, 1991). Thus, susceptibility of fruit to high $\mathrm{CO}_{2}$ is analogous to susceptibility to low $\mathrm{O}_{2}$, where differences in fruit tissue thresholds to injury appear to exist in different cultivars (Park et al., 1993).

None of the physiological factors measured in this study were consistently associated with BBD occurrence. Because of the high variation among orchards, we also analyzed all data sets by pairwise scatter plot comparisons in an attempt to detect relationships between factors measured in this study and BBD that might be missed by comparison of treatment effects. However, no factor was related significantly to BBD (data not shown).

The primary factors affecting BBD development are unknown but are probably associated with tissue tolerance to $\mathrm{CO}_{2}$ concentrations in the fruit. While maturity, mineral content, and skin permeance are all potential factors contributing to susceptibility of 'Braeburn' fruit to BBD, they probably have secondary rather than primary roles. For example, bitter pit and breakdown are usually described as disorders associated with low $\mathrm{Ca}$ in the fruit (Ferguson and Watkins, 1989; Marmo et al., 1985), but their incidence can be low even in susceptible fruit when harvested at certain maturity stages (Watkins et al., 1989).

From a practical standpoint, we conclude that late harvested fruit and/or fruit from low cropping trees grown in at-risk regions have a moderate to high risk of developing $\mathrm{BBD}$ during storage. If an orchard is found to be of high risk due to factors of region, site history, harvest date, crop load, and seasonal influence, then we recommend that fruit from light cropping trees should be segregated by the grower at harvest. Growers should manage crop load to avoid light cropping trees within a block, and reduce the likelihood of biennial cropping by avoiding overcropping or overthinning of flowers and fruitlets.

\section{Literature Cited}

Banks, N.H. 1985. Estimating skin resistance to gas diffusion in apples and potatoes. J. Expt. Bot. 36:1842-1850.

Blanpied, G.D. and R.M. Smock. 1961. Two factorial experiments on controlled atmosphere storage of McIntosh apples. Proc. Amer. Soc. Hort. Sci. 78:35-42.

Bramlage, W.J.,P.H. Bareford, G.D. Blanpied, D.H. Dewey, S. Taylor, S.W. Porritt, E.C. Lougheed, W.H. Smith, and F.S. McNicholas. 1977. Carbon dioxide treatments for 'McIntosh' apples before CA storage. J. Amer. Soc. Hort. Sci. 102:658-662.

Carne, W.M. 1950. Brownheart of apples and its relation to our knowledge of apples and of ship carriage of perishable fruit. J. Austral. Inst. Agr. Sci. 16:59-64.

Elgar H.J., D.M. Burmeister, and C.B. Watkins. 1998. Storage and handling effects on a $\mathrm{CO}_{2}$ related internal browning disorder of 'Braeburn' apples. HortScience 33:719-722.

Ferguson, I.B. and C.B. Watkins. 1989. Bitter pit in apple fruit. Hort. Rev. 11:289-355.

Ferguson, I.B. and C.B. Watkins. 1992. Crop load affects mineral concentrations and incidence of bitter pit in 'Cox's Orange Pippin' apple fruit. J. Amer. Soc. Hort. Sci. 117:373-376.

Johnson, D.S., C.J. Dover, and R.J. Colgan. 1998. Effect of rate of establishment of CA conditions on the development of $\mathrm{CO}_{2}$-injury in Bramley's Seedling apples. Acta Hort. 464:351-356.

Lau, O.L. 1998. Influence of climate, harvest maturity, waxing, $\mathrm{O}_{2}$ and $\mathrm{CO}_{2}$ on browning disorders of 'Braeburn' apples. Postharvest Biol. Technol. $14: 131-141$

Lau, O.L. and N.E. Looney. 1978. Effects of a prestorage high $\mathrm{CO}_{2}$ treatment on British Columbia and Washington State 'Golden Delicious' apples. J. Amer. Soc. Hort. Sci. 103:341-344.

Lay-Yee, M. 1993. Response of New Zealand apples to methyl bromide fumigation. Orchardist of New Zealand 10:35-36.

Lidster, P.D., G.D. Blanpied, and R.K. Prange. 1990. Controlled-atmosphere disorders of commercial fruits and vegetables. Agr. Can. Publ. 1847/E. p. 7-11; 15-18.

Marmo, C.A., W.J. Bramlage, and S.A Weis. 1985 Effects of fruit maturity, size, and mineral concentrations on predicting the storage life of 'McIntosh' apples. J. Amer. Soc. Hort. Sci. 110:499-502.

Meheriuk, M. 1977. Treatment of Golden Delicious apples with $\mathrm{CO}_{2}$ prior to CA storage. Can. J. Plant Sci. 57:467-471.

Park, Y.M., G.D. Blanpied, Z. Joswiak, and F.W. Liu. 1993. Postharvest studies of resistance to gas diffusion in McIntosh apples. Postharvest Biol. Technol. 2:329-339.

Park, Y.M. and S. Lee. 1991. Susceptibility of 'Fuji' apples to low-oxygen and high-carbon dioxide injury during CA storage. J. Kor. Soc. Hort. Sci. 33:38-43.

Rajapakse, N.C., N.H. Banks, E.W. Hewett, and D.J. Cleland. 1990. Development of oxygen concentration gradients in flesh tissues of bulky plant organs. J. Amer. Soc. Hort. Sci. 115:793797.

Sharples, R.O. 1964. The effects of fruit thinning on the development of Cox's Orange Pippin apples in relation to the incidence of storage disorders. J. Hort. Sci. 39:224-235.

HortSCIEnCE, Vol. 34(2), ApriL 1999 
Smock, R.M. and G.D. Blanpied. 1963. Some effects of temperature and rate of oxygen reduction on the quality of controlled atmosphere stored McIntosh apples. Proc. Amer. Soc. Hort. Sci. 83:135-138.

Smock, R.M. and G.D. Blanpied 1972. Controlled atmosphere storage of apples. Info. Bul. 41, Cornell Univ., Ithaca, N.Y.

Volz, R.K., W.V. Biasi, J.A. Grant, andE.J. Mitcham 1998. Prediction of controlled atmosphere-induced flesh browning in 'Fuji' apple. Postharvest Biol. Technol. 13:97-107.

Volz, R.K., I.B. Ferguson, J.H. Bowen, and C.B. Watkins. 1993. Crop load effects on fruit mineral nutrition, maturity, fruiting and tree growth of 'Cox's Orange Pippin' apple. J. Hort. Sci. 68:127-137.

Watkins, C.B., E.W. Hewett, C. Bateup, A. Gunson, and C.M. Triggs. 1989. Relationships between maturity and storage disorders in 'Cox's Orange Pippin' apples as influenced by preharvest calcium and ethephon sprays. N.Z. J. Crop Hort. Sci. 17:283-292.

Watkins, C.B., K.J. Silsby, and M.C. Goffinet. 1997. Controlled atmosphere and antioxidant effects on external $\mathrm{CO}_{2}$ injury of 'Empire' apples. HortScience 32:1242-1246.

Wilkinson, B.G. and J.C. Fidler. 1973. Injuries caused by incorrect concentrations of carbon dioxide and/or oxygen, p. 81-87. In: J.C. Fidler,
B.G. Wilkinson, K.L. Edney, and R.O. Sharples (eds.). The biology of apple and pear storage. Res. Rev. 3, Cmwlth. Bur. Hort. Plantation Crops, East Malling, England.

Yearsley, C.W. 1996. Internal lower oxygen limits of apple fruit. PhD Diss., Massey Univ., New Zealand.

Yearsley, C.W., N.H. Banks, and S. Ganesh 1997. Effect of carbon dioxide on the internal lower oxygen limits of apple fruit. Postharvest Biol. Technol. 12:1-13.

Yearsley, C.W., N.H. Banks, S. Ganesh, and D.J. Cleland. 1996. Determination of lower oxygen limits for apple fruit. Postharvest Biol. Technol. 8:95-109. 